\title{
Sarana Sanitasi Dasar dengan Kejadian Diare pada Balita
}

\author{
Asep Irfan', Delima² \\ Poltekkes Kemenkes RI Padang
}

\begin{abstract}
Diarrhea is a public health problem that needs to be considered because it is the third major contributor to child morbidity and mortality. In 2015 the highest incidence of diarrhea occurred in the working area of Pauh Padang Health Center with a percentage of $8.41 \%$, the highest in the South Limau Manis area. This type of research is descriptive analytic with Cross Sectional design. Research from February to August 2016. The population is all households that have children under five in Kelurahan Limau Manis Selatan, Pauh Padang Sub-district. Sampling is proportionally sampled at 73 people. Data were analyzed by frequency distribution with chi square test. The results showed that there was a significant relationship between the conditions of the facilities: the provision of clean water, family latrines, waste water disposal and family waste disposal with the incidence of diarrhea in infants. Through the Puskesmas leadership it is recommended to always activate the environmental health program to conduct counseling on the importance of maintaining household environmental sanitation which includes the provision of clean water, latrines, managing wastewater and managing waste.
\end{abstract}

Keywords: Diarrhea, Clean Water, Human Manure, Waste, Waste Water

\begin{abstract}
Abstrak
Penyakit diare merupakan masalah kesehatan masyarakat yang perlu di perhatikan karena penyumbang utama ketiga angka kesakitan dan kematian anak. Tahun 2015 angka kejadian diare tertinggi terjadi di wilayah kerja Puskesmas Pauh Padang dengan persentase 8,41\% yang tertinggi terdapat di wilayah Limau Manis Selatan. Jenis penelitian adalah deskriptif analitik dengan rancangan Cross Sectional. Penelitian Bulan Februari - Agustus 2016. Populasi adalah seluruh KK yang memiliki balita di Kelurahan Limau Manis Selatan Kecamatan Pauh Padang. Pengambilan sampel secara proporsional sampling sebesar 73 orang. Data dianalisis secara distribusi frekuensi dengan uji statistik chi square. Hasil penelitian menunjukkan terdapat hubungan yang bermakna antara kondisi sarana: penyediaan air bersih, jamban keluarga, pembuangan air limbah dan pembuangan sampah keluarga dengan kejadian diare pada balita. Melalui Pimpinan Puskesmas disarankan untuk selalu mengaktifkan progam kesehatan lingkungan mengadakan penyuluhan tentang pentingnya menjaga sanitasi lingkungan rumah tangga yang meliputi penyediaan air bersih, jamban, mengelola air limbah dan mengelola sampah.
\end{abstract}

Kata kunci : Diare, Air Bersih, Kotoran Manusia, Sampah, Air Limbah

\section{PENDAHULUAN}

Penyakit diare merupakan salah satu penyakit yang disebabkan oleh lingkugan yang tidak sehat dan penyakit kedua terbanyak di seluruh dunia setelah infeksi saluran pernafasan akut (ISPA). Penyakit ini diperkirakan ditemukan 1 milyar kasus per tahun dan 
merupakan penyebab utama morbiditas dan mortalitas anak-anak di Asia, Afrika, dan Amerika Latin (Depkes RI, 2010).

Faktor lingkungan berkaitan erat dalam penyebaran penyakti diare, dimana dua faktor yang paling dominan yaitu sarana air bersih dan pembuangan tinja, kedua faktor ini akan berintegrasi bersama dengan perilaku manusia. Apabila faktor lingkungan tidak sehat karena tercemar kuman diare serta berakumulasi dengan perilaku manusia yang tidak sehat pula, yaitu melalui makanan dan minuman maka dapat menimbulkan kejadian penyakit diare ( Kusnoputranto, 2010 ).

Data Dinas Kesehatan Kota Padang (DKK) tahun 2015, angka kejadian diare tertinggi terjadi di Puskesmas Pauh Padang dengan jumlah 659 kasus dari jumlah 7827 kasus di seluruh Puskesmas Kota Padang dengan persentase (8,41\%). Dari 659 kasus tersebut wilayah tertinggi kasus diare terdapat di Wilayah Limau Manis Selatan dengan angka kejadian diare sebanyak 202 kasus (25,8\%). Kasus diare yang terbanyak terjadi pada balita (bawah 5 tahun) sebanyak 129 kasus (63,8\%) (Laporan Puskesmas Pauh, 2015).

Dari studi pendahuluan ditemui data kondisi SAB (sarana air bersih) memenuhi syarat sebanyak 48,2\%, kondisi memiliki JAGA (jamban keluarga) sebanyak $82,1 \%$ dan memenuhi syarat sebanyak 51,4\%, yang memilikii SPAL (Sarana Pengelolaan Air Limbah) sebanyak $23,9 \%$ dan memenuhi syarat sebanyak $77,2 \%$ dan kondisi memiliki pengelolaan sampah sebanyak 29,8\% dan memenuhi syarat sebanyak 59,2\% (Profil Puskesmas Pauh Padang, 2015).

Oleh karena itu peneliti tertarik untuk meneliti hubungan antara sarana sanitasi dasar dengan kejadian diare pada balita di di Kelurahan Limau Manis Selatan Wilayah Kerja Puskesmas Pauh Padang Tahun 2016.

\section{METODE PENELITIAN}

Jenis penelitian ini adalah analitik dengan desain cross sectional study dimana Variabel Independen berupa sarana sanitasi berupa kondisi sarana air bersih, kondisi sarana jamban keluarga, kondisi sarana pembuangan air limbah, kondisi sarana pembuangan sampahdan variabel dependen (Kejadian Diare). Penelitian telah dilakukan di Kelurahan Limau Manis Selatan Wilayah Kerja Puskesmas Pauh Padang pada bulan Februari sampai dengan Agustus 2016.

Populasinya adalah semua balita (bawah lima tahun) yang tercatat di Kelurahan Limau Manis Selatan Wilayah Kerja Puskesmas Pauh Padang 671 orang. Besar sampelnya didapatkan sampel 73 orang. Tehnik pengambilan sampel dilaksanakan menggunakan proporsional sampling dari masing-masing posyandu yang ada di Kelurahan Limau Manis Selatan (10 Posyandu Balita), 
Untuk variabel indevenden didapatkan dengan cara melakukan observasi langsung/ inspeksi sanitasi ke rumah responden. Untuk Variabel Dependen dengan cara melakukan wawancara langsung pada ibu yang mempunyai balita tentang keluhan subjektif perubahan konsistensi tinja. Data dianalisis secara univariat dengan menggunakan distribusi frekuensi dan analisis bivariat dengan menggunakan uji Chi Square $\left(x^{2}\right)$ hasil analisis bermakna jika nilai $p$ value $\leq 0,05$.

\section{HASIL PENELITIAN}

Tabel 1. Karakteristik Responden

\begin{tabular}{lrc}
\hline Variabel & Jumlah & $\%$ \\
\hline Pendidikan: & 9 & 12,3 \\
SD & 11 & 15,1 \\
SMP & 47 & 64,4 \\
SMA & 6 & 7,7 \\
PT & & \\
& & 90,4 \\
Status Pekerjaan lbu: & 66 & 9,6 \\
Ibu RT & 7 & \\
Bekerja & & \\
\hline
\end{tabular}

Tabel 1 menunjukkan tingkat pendidikan responden yang terbanyak adalah SMA $(64,4 \%)$. Status pekerjaan responden sebagian besar $(90,4 \%)$ ibu rumah tangga.

\section{Analisis Univariat}

Tabel 2. Distribusi Responden Berdasarkan Kejadian Diare dan Sarana Sanitasi Dasar Keluarga di Kelurahan Limau Manis Selatan Wilayah Kerja Puskesmas

\begin{tabular}{lcc}
\hline Variabel & Jumlah & $\%$ \\
\hline Kejadian Diare: & 45 & 61,6 \\
$\quad$ Diare & 28 & 38,4 \\
$\quad$ Tidak Diare & & \\
Kondisi Sarana Penyedian Air Bersih: & 34 & 46,6 \\
$\quad$ Berisiko & 39 & 53,4 \\
$\quad$ Tidak Berisiko & & \\
Kondisi Jamban Keluarga: & 32 & 43,8 \\
$\quad$ Berisiko & 41 & 56,2 \\
$\quad$ Tidak Berisiko & & \\
$\quad$ & 36 & 49,3 \\
Kondisi Pembuanga Air Limbah & 37 & 50.7 \\
$\quad$ Berisiko & & \\
$\quad$ Tidak Berisiko & & 84,9 \\
Kondisi Pembuangan Sampah & 62 & 15,3 \\
$\quad$ Berisiko & 11 & \\
$\quad$ Tidak Berisiko & &
\end{tabular}


Berdasarkan tabel 2 terdapat 38,4\% responden yang mengalami diare. Mengenai sarana sanitasi lingkungan keluarga ternyata kondisi pembuangan sampah keluarga yang paling besar faktor rikonya $(84,9 \%)$.

\section{Analisis Bivariat}

Tabel 3. Hubungan Sarana Sanitasi Dasar Keluarga dengan Kejadian Diare Pada Balita di Kelurahan Limau Manis Selatan Wilayah Kerja Puskesmas

\begin{tabular}{|c|c|c|c|c|c|c|c|}
\hline \multirow{2}{*}{$\begin{array}{c}\text { Kondisi Sarana } \\
\text { Sanitasi Dasar } \\
\text { Keluarga }\end{array}$} & \multicolumn{4}{|c|}{ Kejadian Diare } & \multirow[b]{2}{*}{ Jumlah } & \multirow[b]{2}{*}{$\%$} & \multirow[b]{2}{*}{ p Value } \\
\hline & Diare & $\%$ & $\begin{array}{l}\text { Tidak } \\
\text { Diare }\end{array}$ & $\%$ & & & \\
\hline \multicolumn{8}{|c|}{$\begin{array}{l}\text { Kondisi Sarana } \\
\text { Penyediaan Air Bersih }\end{array}$} \\
\hline Beresiko & 26 & 76,5 & 8 & 23,5 & 34 & 100 & 0,028 \\
\hline Tidak Beresiko & 19 & 48,7 & 20 & 51,3 & 39 & 100 & \\
\hline \multicolumn{8}{|l|}{$\begin{array}{l}\text { Kondisi Sarana } \\
\text { Jamban Keluarga }\end{array}$} \\
\hline Beresiko & 25 & 78,1 & 7 & 21,9 & 32 & 100 & 0,021 \\
\hline Tidak Beresiko & 20 & 48,8 & 21 & 51,2 & 41 & 100 & \\
\hline \multicolumn{8}{|l|}{$\begin{array}{l}\text { Kondisi Sarana } \\
\text { Pembuangan Air }\end{array}$} \\
\hline $\begin{array}{l}\text { Limbah } \\
\text { Beresiko }\end{array}$ & 31 & 72,1 & 12 & 27,9 & 43 & 100 & 0,011 \\
\hline Tidak Beresiko & 14 & 46,7 & 16 & 53,3 & 30 & 100 & \\
\hline \multicolumn{8}{|l|}{$\begin{array}{l}\text { Kondisi Sarana } \\
\text { Pembuangan }\end{array}$} \\
\hline $\begin{array}{l}\text { Sampah } \\
\text { Beresiko }\end{array}$ & 42 & 67,7 & 20 & 32,3 & 62 & 100 & 0,017 \\
\hline Tidak Beresiko & 3 & 27,3 & 8 & 72,7 & 11 & 100 & \\
\hline
\end{tabular}

Dari ke 4 indikator sarana sanitasi dasar keluarga semuanya berhubungan dengan kejadian diare yaitu sarana pembuangan air limbah, kondisi sarana pembuangan sampah keluarga, kondisi sarana jamban keluarga dan dan penyediaan air bersih keluarga.

\section{PEMBAHASAN}

Terdapat hubungan yang bermakna antara kondisi sarana: penyediaan air bersih, jamban keluarga, pembuangan air limbah dan pembuangan sampah keluarga dengan kejadian diare pada balita di Kelurahan Limau Manis Selatan wilayah kerja Puskesmas Pauh.

Hasil penelitian ini sejalan dengan penelitian yang dilakukan oleh Tukan (2010) tentang hubungan kondisi sarana sanitasi dasar perumahan terhadap kejadian diare di Kelurahan Ekasapta Wilayah kerja Puskesmas Larantuka Kabupaten Flores Timur menunjukan adanya hubungan sarana sanitasi dasar perumahan dengan kejadian diare . 
Terbukti bahwa penyediaan air bersih akan mempengaruhi terhadap dengan kejadian diare. Hal ini dapat disebabkan karena dengan kondisi air yang beresiko akan banyak mengandung kuman penyakit yang beresiko terhadap terjadinya diare. Sesuai dengan pendapat Notoadmodjo (2010) bahwa keperluan minum (termasuk masak) air harus mempunyai syarat khusus agar air tersebut tidak menimbulkan penyakit bagi manusia.

Diare adalah buang air besar dengan frekuensi yang tidak normal (meningkat) dan konsistensi tinja yang lebih lembek atau cair, istilah gastroenteritis hendaknya dikesampingkan saja, karena memberikan kesan terdapatnya suatu radang sehingga selama ini penyelidikan tentang diare cenderung lebih ditekankan pada penyebabnya (Suharyono, 2008). Diare adalah perubahan frekuensi dan konsistensi tinja. WHO pada tahun 1984 mendefinisikan diare sebagai berak cair 3 kali atau lebih dalam sehari semalam (24 jam).Diare yang berkepanjangan dapat menyebabkan dehidrasi atau kekurangan cairan (Widoyono, 2011).

Pada penelitian ditemukan bahwa cukup banyak balita yang mengalami diare. Hal ini dapat disebabkan beberapa faktor yaitu salah satunya faktor kondisi sanitasi lingkungan yang beresiko. Pada penelitian ditemukan bahwa 46,6\% keluarga mempunyai penyediaan air bersih yang beresiko, $43,8 \%$ keluarga mempunyai pembuangan kotor manusia yang beresiko, $84,9 \%$ keluarga mempunyai pengelolaan sampah yang beresiko dan keluarga $(49,3 \%)$ mempunyai pengelolaan air limbah yang beresiko. Penelitian WHO di Indonesia (34) telah memperlihatkan bahwa lingkungan (termasuk lingkungan kesehatan) sangat berpengaruh terhadap kesehatan dan taraf ekonomi Negara Indonesia (Soemirat, 2011).

Zat-zat yang terkandung dalam air limbah ini maka air limbah yang tidak diolah terlebih dahulu akan menyebabkan berbagai gangguan kesehatan masyarakat dan lingkungan hidup antara lain : 1) Menjadi transmisi atau media penyebaran berbagai penyakit terutama: kolera,tifus abdominalis, desentri baciler, 2) Menjadi media berkembang biaknya mikroorganisme pathogen, 3) Menimbulkan bau yang tidak sedap, serta pandangan yang tidak enak, 4) Merupakan sumber pencemaran air permukaan tanah dan lingkungan hidup lainnya, 5) Mengurangi produktivitas manusia, karena orang bekerja tidak nyaman, dan sebagainya (Notoadmodjo, 2010).

Pengelolaan sampah beresiko maka besar kemungkinan terjadinya diare dibandingkan dengan pengelolaan sampah yang tidak beresiko. Hal ini dapat disebabkan karena dengan pengelolaan sampah yang beresiko maka akan menjadi media berkembanganya binatang dan serangga sebagai pemindah/penyebab penyakit (vector) yang beresiko terhadap terjadinya diare. Sesuai dengan pendapat Notoadmodjo (2010) bahwa sampah erat kaitannya dengan kesehatan masyarakat, karena dari sampah tersebut 
akan hidup mikroorganisme penyebab penyakit (bakteri pathogen), dan juga binatang dan serangga sebagai pemindah/penyebab penyakit (vector).

Berdasarkan hal ini maka menurut analisa peneliti terhadap penelitian ini adalah ditemukan bahwa cukup banyaknya balita yang mengalami diare. Hal ini harus segera diatasi karena akan berdampak terhadap status gizi anak bahkan bisa menyebabkan kematian pada balita. Dalam hal ini perlu adanya upaya dari petugas kesehatan terutama petugas kesehatan lingkungan untuk memberikan penyuluhan kepada masyarakat tentang diare dan mengelola lingkungan menjadi lingkungan yang lebih sehat.

\section{SIMPULAN DAN SARAN}

Terdapat hubungan yang bermakna kondisi sarana penyediaan air bersih, kondisi sarana jamban keluarga, kondisi sarana pembuangan air limbah keluarga dan kondisi sarana Pebuangan sampah dengan kejadian diare pada balita di Kelurahan Limau Manis Selatan Wilayah kerja Puskesmas Pauh Padang Tahun 2016.

Saran yang direkomendasikan kepada pimpinan Puskesmas Pauh Padang untuk selalu mengaktifkan progam kesehatan lingkungan dalam memberikan penyuluhan yang kontinyu tentang pentingnya menjaga sanitasi dasar rumah tangga, jika perlu melakukan lomba sanitasi lingkungan rumah (lomba rumah sehat), agar terhindar terjadinya diare.

\section{DAFTAR PUSTAKA}

Arikunto .S, 2010, Prosedur Penelitian Suatu Pendekatan Praktek Edisi Revisi VI, Jakarta : Rineka Cipta

Depkes RI, 2010, Buku Pedoman Kader Untuk Pemberantasan Diare, Direktorat Jendral PP \& PL, Jakarta.

Departemen Kesehatan Republik Indonesia .Laporan Hasil Riset Keshatan Dasar Indonesia(Riskesdas2013)http://www.depkes.go.id/resources/download/general/H asil\%20Riskesdas\%202013.pdf (di unduh 6 Juni 2015 pukul 16.00 wib)

Kusnoputranto, Haryoto dan Dewi Susanna, 2000, Kesehatan Lingkungan, Jakarta : FKM Universitas Indonesia

Notoadmodjo, S 2010 ,Promosi Kesehatan Teori Dan Aplikasi, Jakarta : Rineka Cipta

Soemirat Juli .2011,Kesehatan Lingkungan, Gajah Mada University

Suharyono.2008,Diare Akut Klinik dan Laboratorik,Jakarta : Rineka Cipta

Tukan, Andreasratu 2007, Hubungan Kondisi Sarana Sanitasi Dasar Perumahan Terhadap Kejadian Diare Di Kelurahan Ekasapta Kecamatan Larantuka Kabupaten Flores Timur (Http://Lib.Unair.Ac.Id/Go.Php?ld=Gdhub-Gdlhub-Gdl-S1)

Widoyono.2011.Penyakit Tropis Epidemiologi, Penularan, Pencegahan, Dan

Pemberantasan Edisi Kedua, Semarang : Erlangga 